\title{
Comments
}

\section{PROBATION IN CALIFORNIA: PENAL CODE SECTION 1203}

Since 1903, California has recognized probation as a method of dealing with convicted defendants. It importance in the postconviction process is illustrated by its use; since 1953, it las been granted to over forty per cent of those convicted of felonies in this state. ${ }^{2}$ In part this large use can be explained by sentencing procedures in California. While in misdemeanor cases the judge determines the amount of pumshment within the statutorily prescribed minimum and maximum, this is not true in felony cases. In felony cases, the court merely sentences the defendant to the term prescribed by statute or grants probation. The length of incarceration is determined by the Adult Authority. ${ }^{3}$ Thus, the only discretion the trial judge lias as to the amount of punishment is found in the use of probation and conditions of probation. ${ }^{4}$

Despite the widespread use of probation and despite the fact that the court can only grant probation because of statutory authorization, ${ }^{5}$ the basic statute authorizing probation, Penal Code section $1203,{ }^{6}$ is inconsistent, prolix, and exceedingly intricate.

The purposes of this comment are first, to analyze and interpret section 1203; second, to examine the substantive merit of the statute, especially the portion that hinits judicial power to grant probation; and third, to suggest a statute that will contain the substance of the present statute in a more understandable form. Before undertaking these tasks, however, a slort examination of the background,

\begin{tabular}{|c|c|}
\hline \multicolumn{2}{|c|}{${ }^{1}$ Cal. Stat. 1903 , ch. $34, \S 1$, at 34.} \\
\hline YEAR & IN FELONY CASES \\
\hline 1953 & $40.2 *$ \\
\hline 1954 & $45.0 *$ \\
\hline 1955 & $44.2 *$ \\
\hline 1956 & $43.5^{*}$ \\
\hline 1957 & $45.9 * *$ \\
\hline 1958 & $47.4^{* *}$ \\
\hline 1959 & $44.5 * *$ \\
\hline 1960 & $44.3 * *$ \\
\hline 1961 & $45.2 * *$ \\
\hline
\end{tabular}

Source: *State of Calff., Buread of Criminal Statistics, Dep't of Justice, Creme in

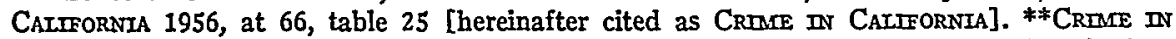
CALIFORNIA 1961, at 119, table VI-16. The court may require, as a condition of probation, that the defendant spend a definite length of time in jail. See note 12 infra.

${ }^{3}$ CAL. PEN. CODE $\$ 3020$.

4 See note 12 infra.

5 The case law establishes that the only way that the court can suspend sentence is by granting probation in accordance with the statutory probation laws. Oster v. Municipal Court, 45 Cal.2d 134, 287 P.2d 755 (1955); People v. Sidwell, 27 Cal.2d 121, 162 P.2d 913 (1945); People v. Bueno, 177 Cal. App. 2d 235, 2 Cal. Rptr. 62 (1960) ; People v. Wallach, 8 Cal. App. 2d 129,47 P.2d 1071 (1935).

6 Other statutes that place limitations on the use of adult probation are CAL. VeHICLE CODE $\$ 23102$ (no probation for second misdemeanor drunk driving offense) and CAL. HEALTE \& SAFETY CODE \$11715.6 (no probation for second narcotics offense). CAL. VEHICLE CODE $\$ 14250$ permits the Departunent of Motor Vehicles to place a person on probation instead of revolsing or suspending his license. 
purpose, and nature of probation is necessary so that a clearer understanding may be had of the ensuing discussion.

Although the common law roots of probation extend back into the 18th century and possibly further, probation as it is known today had its origin in the 19th century in Massachusetts, where John Augustus informally took charge of petty criminals who otherwise would have gone to jail. Massachusetts, in 1878, was the first state to authorize probation by statute. ${ }^{7}$ Several states quickly followed suit and in the 20th century probation bas been recognized not only in this country but throughout the world. ${ }^{8}$

Penal Code section 1203 , the basic statutory provision concerning adult probation in California, was originally enacted in 1872 as a statute authorizing the court to hear evidence in aggravation or mitigation of punishment. ${ }^{\circ}$ In 1903, it was amended to allow the court to place the defendant on probation if there were "circumstances in mitigation of the punishment, or ... the ends of justice [would] be subserved."10 Since then the statute has been amended nineteen times, with particularly significant changes in 1923 , when the first specific restrictions on judicial discretion were enacted, in 1927, 1931, 1949, and 1957, when important modifications of, and additions to, these restrictions were made. ${ }^{11}$

Essentially, probation is a postconviction process which serves as an alternative to incarceration; ${ }^{12}$ it has as its fundamental raison d'être the reformation of the defendant in the society in which he must eventually live. ${ }^{13}$ The defendant is released under the supervision of a probation officer. In California, this release

7 Mass. Acts 1878, ch. 198. This act authorized probation in one county only.

8 For a brief historical outline of probation in the United States see State of CaLre, Spectar Study Compmission on Correctional Factuities and Services, Probation in Calirornia 26-27 (1957) [hereinafter cited as Probation IN CAIIfORMa]. For a more complete history of probation see Chute \& Beir, Crmae, Courts and Probation (1956); Dressler, Practice and Theory of Probation and Parole 6-26 (1959). For the extent of probation outside of the United States see U.N. Dep't of Soctal Affatrs, Probation and Reiated Measures (1951).

0 It provided:

After a plea or verdict of guilty, where a discretion is conferred upon the Court as to the extent of the punishment, the Court, upon the oral suggestion of either party that there are circumstances which may be properly taken into view either in aggravation or mitigation of the punishment, may, in its discretion, hear the same summarily, at a specified time, and upon such notice to the adverse party as it may direct.

The Penal Code of Cahifornia 269 (1872).

10 Cal. Stat. 1903, ch. $34, \S 1$, at 34.

11 See note 44 infra.

12 However, under CAL. PEN. CODE $\S 1203.1$ the court may require as a condition to probation that the defendant spend a definite length of time in jail. This is done quite often. For exainple, im 1961 approximately $44 \%$ of all grants of probation froun California superior courts were conditioned on a jail sentence. CRIME IN CALIFOrNIA 1961, at 124, table VI-18. The percentage varied with the offense committed. Of those granted probation in 1961 who were convicted of robbery, over $84 \%$ served jail ternis as did approximately $58 \%$ of those convicted of homicide and burglary. On the other hand, jail as a condition was imposed on only about $21 \%$ of the defendants granted probation for sex offenses other than rape. Ibid.

In 1961, the average length of time imposed on three-fourths of those placed in jail as a condition of probation was six months or less. $I d$. at 128 . However, over $57 \%$ of those convicted of robbery and $42 \%$ of those convicted of homicide served over six months in jail as a condition of probation. On the other hand, over half of those convicted of auto theft and rape served three months or less. Id. at 129 , table VI- 22 .

13 In California, if he fulfills the conditions of probation for the entire period, he may have the accusation against him dismissed and he may be released from the "penalties and disabilities resulting from the offense." There are, however, himits on this exculpation. See CaL. PEN. Code \$1203.4; Zwerin, Probation and Section 1203.4, Penal Code, 36 CaL. S.B.J. 94 (1961). 
can be accomplished by suspending either the imposition or the execution of the sentence. ${ }^{14}$ The defendant may be subject to reasonable conditions imposed by the court; ${ }^{15}$ his probation can be terminated and he can be incarcerated for violation of these conditions or for the commission of any public offense. ${ }^{16}$ Probation differs from parole; in the latter process the defendant is released only after he has served some portion of the incarceration to which he was sentenced.

\section{I}

\section{ANALYSIS AND INTERPRETATION OF SECTION 1203}

Penal Code section 1203 serves two broad functions. The first is to authorize the trial court to grant probation and to delineate the situations in which it may be granted. This delineation is accomphished by requiring that several broad conditions and a number of specific conditions be present before probation can be granted. The second function of the statute is to outline procedures which the court must follow when it sentences the defendant and when it considers the matter of probation. These procedures are primarily concerned with the presentence report and the hearing. To aid in the following discussion the statute is set forth in full in the appendix with parenthetic numerals added.

\section{A. Procedures}

\section{The Presentence Report}

Ideally, each probation determination, and each passing of sentence where the court has discretion in the extent of punishnient, should be made in light of all the information known about the defendant. This information should be incorporated in a presentence report made to the court by the probation officer. Since $1947,{ }^{17}$ a presentence report has been required in all felony cases in which the defendant is eligible ${ }^{18}$ for probation. ${ }^{19}$ By this requirement California has

14 CAL. PEN. Code $\$ 1203.1$. If the court suspends the imposition rather than the execution of the sentence, it has greater discretion in sentencing a defendant whose probation is revoked.

${ }^{15}$ CAL. PEN. CoDE $\S 1203.1$. The courts have been given a great deal of discretion in imposing these conditions. Some of the more dramatic examples of conditions imposed include People v. Osslo, 50 Cal. 2d 75, 323 P.2d 397 (1958) (labor union officer prohibited from holding any labor union office) ; People v. Alexander, 182 Cal. App. 2d 281, 6 Cal. Rptr. 153 (1960) (arsonist required to make reparation of $\$ 139,036.05$ for losses due to fire); People v. Frank, 94 Cal. App. 2d 740, 211 P.2d 350 (1949) (pediatrician prohibited froin practicing medicine); People v. Blankenship, 16 Cal. App. 2d 606, 61 P.2d 352 (1936) (probationer ordered sterilized). However, the defendant is not required to accept probation and may choose to be sentenced instead. In re Osslo, 51 Cal. 2d 371, 334 P.2d 1 (1958).

16 Cal. Pen. Code $\$ \S 1203.2-3$.

17 Prior to 1929 , it was possible for the court to grant or deny probation in any case without a presentence report. Compare Cal. Stat. 1927, ch. 770, \&1, at 1493, with Cal. Stat. 1929, ch. 737, $\S 1$, at 1384. From 1929 to 1947 the court was able to deny probation without a report but needed a report to grant probation in felony cases.

18 Section 1203 makes no provision as to which defendants are "eligible" for probation, but merely defines one group which cannot get probation im any case and another in which probation can only be granted in "unusual cases." See appendix, parts $(7),(8),(9)$, and (10) of statute. The question thus arises whether the court must require and consider a presentence report in any case which comes under the "unusual cases" paragraph, i.e. an arnied robbery, burglary, or arson. Or may it ask for a presentence report only when it thimks that the report may disclose information which makes the case "unusual"? The former is probably more consistent with a desire for rational judicial decision making. For a clue to actual practice see People v. Jones, 203 A.C.A. 241, 21 Cal. Rptr. 290 (1962).

${ }^{19}$ See appendix, part (2) of statute. 
taken a step towards rational sentencing which other jurisdictions have not yet taken. ${ }^{20}$ In misdemeanor cases, however, the court may deny or grant probation without a presentence report. ${ }^{21}$ Although this may permit sentencing without important facts being brought to the attention of the court, the practicalities of the situation appear to compel it. ${ }^{22}$

Section 1203 also prescribes the contents of the presentence report, ${ }^{28}$ requires that it be accompanied by the probation officer's recommendations as to the granting or denying of probation, ${ }^{24}$ and makes the report available to the court and to both attorneys. ${ }^{25}$

When probation is denied, the clerk must send a copy of the report and recommendations to the Department of Corrections at the prison or other institution to which the defendant is delivered. Another report is required of the probation officer by Penal Code section $1203 \mathrm{c}$ whenever a person is sentenced to prison. The code requires this report to be made to the "State Board of Prison Directors"-a now nonexistent imstitution. The report form is quite brief and this requirement is at most a duplication of the presentence report which must be forwarded when probation is denied. In addition, another investigation is made of the committed defendant by the Department of Corrections. For these reasons the $1203 \mathrm{c}$ requirement can probably be elimmated.

20 See Chute \& Beti, Crome, Courts and Propatton 139 (1956).

21 See appendix, part ( 6 ) of statute. Language in part (2) of the statute which seems to be in conflict with part (6) can be ignored. See 16 OPs. CAL. ATT'y GeN. 72 (1950).

22 Figures available indicate that in the years 1953 to 1957 probation was granted to roughly $30 \%$ of the convicted misdemeanants, compared with the $40-45 \%$ probation grants in felony cases in those years. However, because there were roughly thirty times as many misdemeanor convictions as felony convictions, the number of misdemeanants granted probation was much larger. Probation in Californta 31.

To require a presentence report in every misdemeanor case might be to impose an impossible burden on the probation departments. The case load of the average probation officer in California is considerably ahove recommended standards. The National Probation and Parole Association suggest a maximum of fifty casework units. Reed, Caseloads, 3 NPPA J. 142 (1957). The average adult caseload in 1956 in California was estimated at 244. Probation IN CarIFORNIA 17. Further, a mandatory presentence report in misdemeanor cases would considerably slow down procedures in lower courts due to the wait for the report.

23 CAL. Pen. CODE $\$ 1203$ requires the report to contain the "circumstances surrounding the crime and of the prior record and history of the defendant." CAL. PEN. CODE $\$ 1203.10$ is apparently a particularization of section 1203 and not in conflict with it. On judicial recognition of the broad scope of the report see, People v. Overton, 190 Cal. App. 2d 369, 11 Cal. Rptr. 885 (1961).

24 In a very large percentage of cases the recommendations of the probation officer is followed. In 1960, in California superior courts, the probation officer recommended for probation in 9,001 cases and the court followed this recommendation in 8,681 , or $96.4 \%$ of the cases. The probation officer recommended against probation in 12,273 cases. Prohation was denied in 10,698 cases (87.2\%). State of CactF., Bureau of Crtaminal Statistics, Dep't of Justice, Deinnquency and Propation in Carifornia 148-49 (1960).

25 See appendix, part (4) of statute. This requirement is meant to afford procedural fairness to the defendant since it gives him the opportunity to meet the contents of a report which may contain much hearsay, and which greatly affects him. Sce STATE OF CALTF., FourTr Proo-

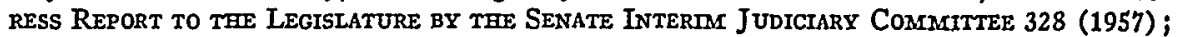
Wyzanski, A Trial Judge's Freedom and Responsibility, 65 HARv. L. REv. 1281, 1291-92 (1952); Comment, Employment of Social Investigation Reports in Criminal and Juvenile Proceedings, 58 CoLUM. L. REv. 702, 704-08 (1958). The argument against the availability of the report is that it will dry up the probation officer's sources of information. See Wilson, $A$ New Arena is Emerging to Test the Confidentiality of Presentence Reports, Fed. Prob., Dec. 1961, p. 6.

The section requires that the report be made available and not that a copy be given to the attorney. The actual practices vary with the probation department. 
By the provisions of the final paragraph of section 1203, the court is given the power to require a presentence report even if the defendant is ineligible for probation. This provision is intended to give the court information on determining the sentence to impose where it has discretion in that respect. This report may also be used by the Department of Corrections and the Adult Authority. Since the report may contain information on environment which would otherwise be unavailable to those bodies, the report should probably be made mandatory in all felony cases whether the defendant is eligible for probation or not.

\section{The Hearing}

"At the time or times fixed by the court" ${ }^{26}$ it inust hold a hearing; ${ }^{27}$ apparently the purpose of this hearing is twofold. Primarily the hearing is to determine the matter of probation. ${ }^{28}$ However, the court may also consider matters in aggravation or mitigation of punishment when it has discretion as to the ainount of punisliment. ${ }^{29}$

The learing must be in the presence of the defendant ${ }^{30}$ and the court must consider the probation officer's report. ${ }^{31}$ If the court determines that the case inerits probation it has the power to place the defendant on probation and to impose con-

26 Appendix, part (5) of statute. The time to pronounce judgment may be extended to consider the matter of probation. CAL. PEN. CODE $\S \S 1191,1449$.

27 See appendix, part $(5)$ of statute. It is not required that the same judge who presided at the defendant's trial preside at the probation determination. People v. Grant, 203 A.C.A. 542, 21 Cal. Rptr. 614 (1962); People v. Connolly, 103 Cal. App. 2d 245, 229 P.2d 112 (1951).

28 At the hearing the court must "determine ... the suitability of probation in the particular case." Appendix, part (5) of statute. The courts have beld that if the defendant is eligible for probation the trial court must determine the matter of probation on its inerits. People v. Walters, 190 Cal. App. 2d 98, 11 Cal. Rptr. 597 (1961); People v. Hollis, 176 Cal. App. 2d 92, 1 Cal. Rptr. 293 (1959).

29 Originally section 1203 related solely to matters in aggravation or mitigation of punishment. See note 9 supra. Presently the statute provides that the presentence report shall inelude "circumstances surrounding the crime and concerning the defendant and his prior record, which may be taken into consideration either in aggravation or mitigation of punishment." (Emphasis added.)

30 See appendix, part (1) of statute. Although the first sentence of the section requires this only in nonfelony cases, there appears to be no good reason for extending procedural fairness to misdemeanants and not to felons. The history of this portion of the statute supports this view. Prior to 1947, the section did not contain the plrase "not amounting to a felony." The purpose of the 1947 amendment was to prohibit the court from summarily denying probation in felony cases and the language "not amounting to a felony" was inserted seemingly without regard for the literal anomaly it created.

31 The court must also make a statement that it has considered the report. See appendix, part (5) of statute. In addition, the defendant lias a right to present matters which may aid him in getting probation or reducing the amount of his sentence. People v. Valdivia, 182 Cal. App. 2d 145, 5 Cal. Rptr. 832 (1960).

The court may not consider matters which are not in the presentence report or presented in open court. CAI. PEN. CODE \$ 1204; People v. Lichens, 202 A.C.A. 673, 21 Cal. Rptr. 41 (1962). However, it is generally assumed that the court does not consider irrelevant matters which may be contained in the presentence report. People v. Wooten, 181 Cal. App. 2d 462, 5 Cal. Rptr. 433 (1960) ; People v. Warren, 175 Cal. App. 2d 233, 346 P.2d 64 (1959).

The presentence report on which the court makes its determination should be current. In People v. Rojas, 57 A.C. 703, 21 Cal. Rptr. 564, 371 P.2d 300 (1962), fifteen montlis elapsed between the time the original report was made and the time the judgment was pronounced. The appellate court required a new presentence report. 
ditions of probation, as provided for in sections $1203.02,,^{32} 1203.1,{ }^{33} 1203 a,{ }^{34}$ and $1215^{35}$ of the Penal Code.

\section{Timing and Other Procedural Matters}

Section 1203 provides that the formal probationary process takes place "after conviction $^{36}$ by plea or verdict of guilty ${ }^{37}$ of a public offense." Although this phrase appears to be limited by the phrase "not amounting to a felony," both felony and nonfelony probation takes place after the defendant's guilt is established. Therefore, with respect to timing, the phrase "not amounting to a felony" is probably without meaning. ${ }^{38}$

In felony cases, if the defendant is eligible for probation, there is no need for an application to be made to initiate the reporting and hearing procedures..$^{30} \mathrm{On}$ the other hand, while an application is not necessary to enable the court to consider probation in misdemeanor cases, the court may refuse to consider the matter of probation even if an application is made by either the defendant or the prosecution. ${ }^{40}$

32 CAL. Pen. Code $\$ 1203.02$ deals specifically with granting probation to violators of offenses enumerated in CAL. PEN. Code $\$ 290$.

${ }^{33}$ CAI. PEN. CoDE $\S 1203.1$ provides that the court may suspend the imposition or the execution of the sentence. The court is authorized to impose jail, reparation, or fine as a condition of probation, or other enumerated conditions or "other reasonahle conditions." The section fixes the term of probation to be "such period of time not exceeding the maximum possible term of such sentence" in all cases, except those in which the term is less than five years, in which case the period of probation imposed may be up to five years. It provides that the probationer shall be under the supervision of a probation officer.

34 CAL. PEN. CODE $\$ 1203$ a provides, inter alia, that courts having the power to impose punishment in misdemeanor cases can "enforce the terms of probation for a period not to exceed three years." This section appears to be in conflict with the provisions of $\S 1203.1$. Fayad v. Superior Court, 153 Cal. App. 2d 79, 313 P.2d 669 (1957), has interpreted 1203.1 as applicable to felonies and 1203a as applicable to misdemeanors. However, when this case was decided both sections provided for three-year maximums and the interpretation was only by way of illustration. Dicta in Oster v. Municipal Court, 45 Cal.2d 134, 287 P.2d 755 (1955) and People v. Rye, 140 Cal. App. 2d Supp. 962, 296 P.2d 127 (Cal. Super. Ct. 1956) appear to contradict Fayad. Therefore, the question is apparently still open.

35 Cat. Pen. Code $\$ 1215$ provides that the probationer must be placed under the supervision of a probation officer. This requirement is a duplication of the requirement of $\S 1203.1$. Section 1215 makes the supervision applicable to all probationers "over the age of sixteen years." This reference to age relates to $\$ 1203$ as it read in 1903 and an examination of the history of $\S 1215$ indicates that it has not been amended since that year. Therefore, the portions dealing with probation probably can be eliminated.

36 The initial words of the section, "after the conviction," indicate that in California probation is clearly a postconviction procedure. Although quite rare, preconviction probation does exist in some areas-notably Norway. U.N. DEP'T OF Soctal AFFATRS, Probation AND RELATED MeAsures 189-92 (1951). This method has also been used in a few jurisdictions in the United States. $I d$. at 89.

37 "By plea or verdict of guilty" indicates that there is no need for the defendant to plead guilty to be eligible for probation. Although at one time some of the judiciary believed that a plea of guilty was a prerequisite to probation, the case law and the language of the statute clearly indicate otherwise. See People v. Miller, 112 Cal. App. 535, 297 Pac. 40 (1931); People v. Jones, 87 Cal. App. 482, 262 Pac. 361 (1927).

38 See note 30 supra.

${ }^{39}$ See appendix, part (5) of statute which provides, inter alia, that the court "must hear and determine such application [for probation], if one has been made, or in any case the suitability of probation in the particular case ...." (Emphasis added.)

${ }^{40}$ See appendix, part (1) of statute which provides, inter alia, "After the conviction . . of a public offense not amounting to a felony ... the court, upon application of the defendant or of the people or upon its own motion may summarily deny probation ...." (Emphasis added.) 
Section 1203 also provides that before the release of any probationer to enter another state the case shall be "referred to the California Administrator, Interstate Probation and Parole Compacts, pursuant to the Uniform Act for Out-ofState Probationer and Parolee Supervision." Since this provision relates to a postdisposition process it would more logically be placed in Penal Code section 1203.1 which relates to supervision of the probationer.

\section{B. The Conditions Necessary for Probation}

\section{The Broad Conditions}

Section 1203 provides that the trial court may grant probation "in cases where discretion is conferred on the court or any other board or commission or other authority as to the extent of punishment." ${ }^{11}$ Although this provision is quite general in appearance, it is of hittle importance in limiting the use of probation. ${ }^{42}$

The statute allows the court to place the defendant on probation "If the court shall determine that there are circumstances in mitigation of punishment prescribed by law, or that the ends of justice would be subserved ...." (Emphasis added.) These conditions are so broad that no litigation can be expected to result from them. However, it is odd that they are alternative conditions to probation since the "ends of justice" condition is broad enough to subsume the "circumstances in mitigation" requirement. The latter is a carry over from the 1872 statute; it is arguable that it should be discarded because it places too much emphasis on the leniency aspect of probation rather than viewing probation as an integral part of the postconviction process. ${ }^{43}$

\section{The Specific Conditions}

Since 1923, Penal Code section 1203 has contained limitations on the types of defendants to whom, and the classes of offenses for which, probation can be

41 This rather awkward terminology can best be understood in its historical context. Since until 1903 CAI. PEN. CODE $\S 1203$ dealt with matters in mitigation and aggravation of punishment, it was quite natural to hmit hearing on these matters to cases in which "discretion is conferred upon the court" to determine the extent of punishment. In other cases the hearing would be no more than a useless act. When probation was authorized in 1903, the phrase remained, and in 1923 it was amended to its present form.

42 Assuming that the term "board or commission or any other authority" includes the Adult Authority in its capacity to fix terms for parole, the language limiting ability to grant probation would be applicable only when the death sentence or life imprisonment without possibility of parole is mandatory. This would include treason (CAL. PEN. CODE $\$ 37$ requires that the punishınent "shall be death"); kidnapping if bodily injury occurs (CAI. PEN. CODE § 209 provides for a mandatory death sentence or life imprisoninent without possibility of parole); trainwrecking offenses (CAI. PEN. CODE \$\$ 218, 219 provide death or life imprisonment without parole depending on the exact offense); and possibly, procuring the conviction and execution of an innocent person (CAI. PEN. CODE $\$ 128$ provides that this offense "is punishable by death").

43 The text writers are quick to point out that the characterization of probation as an act of lemiency is not valid. Cf. U.N. Dep't of Soctat Affatrs, Probation and Related MeasURES 8 (1951). Nevertheless, the cases continue to characterize it as such. People v. Haimline, 219 Cal. 532, 28 P.2d 16 (1933); People v. Walters, 190 Cal. App. 2d 98, 11 Cal. Rptr. 597 (1961) ; People v. Brown, 172 Cal. App. 2d 30, 342 P.2d 410 (1959). With respect to the defendant, of course, probation is generally less onerous than incarceration. However, as viewed from the standpoint of society, probation must be viewed as something more than mere grace or leniency. Its widespread use, see note 2 supra, is not consistent with such a view. 
granted. ${ }^{44}$ The deletions, additions, and modifications have produced a rather complicated statute. At present the most difficult and pressing problem of interpretation concerns the meaning to be given to part $(7)^{45}$ since, with respect to $(7 a)$ and $(7 b)$, this part is in direct conflict with $(a)$ and $(b)$ of part (8). Part (7) allows probation to be granted in "unusual cases" to "a defendant who used or attempted to use a deadly weapon upon a human being in connection with the perpetration of the crime of which he was convicted," or to "one who in the perpetration of the crime of which he was convicted wilfully inflicted great bodily injury or torture," while part (8) absolutely prohibits probation in these situations.

While the words of the statute offer no solution to this inconsistency, four alternatives appear possible as methods of obviating the inconsistency. First, $(7 a)$ and $(7 b)$ could be rendered meaningless by $(8 a)$ and $(8 b)$. This solution is unsatisfactory because it does not explain why the legislature allowed the language to be added. Keeping in mind the rule of construction that all parts of a statute should be given meaning if possible, ${ }^{46}$ and barring complete oversight by the legislature, this alternative should be discounted. Second, $(8 a)$ and $(8 b)$ could be rendered devoid of meaning; thus probation would be available in any "unusual" case even if great bodily injury was inflicted or a deadly weapon was used. This solution presents much the same problem as the first. Moreover, even though the court could then literally grant probation in "unusual cases" to a defendant who

44 The 1923 amendment prohibited the court from granting probation in cases of: murder, robbery, burglary, or rape by force and violence, where in the perpetration of such crimes a deadly weapon is used, or the person committing any of the said crimes was armed with a deadly weapon or where, in the perpetration of any of such crimes, great bodily injury or torture is inflicted, nor to any person who bas been previously convicted of any of said offenses, nor where a public official or employee ... in the discharge of the duties of his public office or employment accepts or gives or offers to accept or give a bribe or embezzles public monies or is guilty of extortion in the discharge of his official duty.

Cal. Stat. 1923, ch. 144, \& 1, at 291. In 1927 the restrictions were modified to make them applicable to any defendant, rather than just those convicted of murder, robbery, burglary or rape with force and violence. Cal. Stat. 1927, cb. 700, §1, at 1493.

The application of this restriction to all crimes was nullified in 1931 and the prohibition was placed on defendants convicted of any one, or more, of sixteen enumerated felonies. Cal. Stat. 1931, ch. 786, § 1, at 1633.

In 1945 two of the enumerated crimes, grand theft and feloniously receiving stolen goods, were deleted from the proscriptions. Cal. Stat. 1945, ch. 765, § 1, at 1448.

In 1949 a significant liberalization of the restrictions was accomplished. Cal. Stat. 1949, ch. $1329, \S 1$, at 2324 . Mayhem and felonious assault with a deadly weapon were deleted from the enumerated crimes. It was required that for a person to be inehigible for probation he must have been "himself" armed with a deadly weapon, and tbat one who used a deadly weapon must use it on a "human being." Further, a person who inflicted great bodily injury must have done so "wilfully." The amendment also made changes with respect to prior felony convictions. It replaced the broad restrictions on persons who bad one prior felony with a restriction on those with two priors. However, persons who committed certam enumerated felonies were still inehgible if they had one prior felony conviction; and any defendant who had committed a prior felony at wbich time he was armed, or used a weapon or inflicted great bodily injury or torture was ineligible.

In 1957 robbery, burglary, and arson were deleted from the absolute prohibitions of the section and what is presently the third paragraph, part (7) of appendix, was added. Cal. Stat. 1957, ch. 2054, § 1, at 3648 (Senate bill 2279).

45 See appendix. The numbers referred to in the text have reference to the parenthetic numerals placed in the statute as set forth there.

48 CaL. Code Civ. Proc. \& 1858. 
used a deadly weapon while perpetrating an offense enumerated under ( 8 ), the court would be prohibited under $(8)$ from granting probation to him because he was armed with the weapon. ${ }^{47}$ A third alternative would allow, in "unusual cases," defendants convicted of robbery, burglary, or arson to be placed on probation even if bodily injury was inflicted or a deadly weapon used. All other offenses would, apparently, come under the provisions of (8). This view is supported by recent dicta. ${ }^{48}$ This interpretation introduces great inequities for persons convicted of less serious crimes since they are barred from probation while an armed robber, for example, would not be..$^{49}$ Finally, $(8 a)$ and $(8 b)$ could be held applicable to only the offenses enumerated in (8), and the provisions of $(7 a)$ and $(7 b)$ applicable to all other offenses. The argument against this interpretation is that the legislature must be presumed to know the existing case law, which establishes that all persons who use a deadly weapon or inflict bodily injury are imeligible for probation, ${ }^{50}$ and that in the absence of any change in the language of $(8)$, must be presumed to have intended that the case law prevail. ${ }^{51}$ Yet since the language is so unclear, this assumption really begs the question of what the legislature did intend.

The intent of the legislature might be reflected in Senate bill 2279 which was introduced into the Cahifornia Senate in January 1957. The main purpose of this bill was to change the introductory clause of what is now the fourth paragrapl (part (8)) to read: "The Legislature hereby expresses the policy of the people of the State of California to be that except in unusual cases where the interest of justice demands a departure from the declared policy, no judge shall grant probation to any person who shall have been convicted of ...." instead of "Probation slall not be granted to any defendant who shall have been convicted of ...." Apparently this hberalization met with some opposition in committee, for the bill was amended to include what is now the third paragrapl (part (7)) of section 1203 and references to robbery, burglary, and arson were deleted from what is now the

47 Both People v. Orrante, 201 A.C.A. 614, 20 Cal. Rptr. 480 (1962) and People v. Superior Court, 199 A.C.A. 326, 18 Cal. Rptr. 557 (1962) have held that this alternative is not valid.

48 People v. Superior Court, 199 A.C.A. 326, 18 Cal. Rptr. 557 (1962).

$49 \mathrm{~A}$ solution which might obviate this difficulty is to permit grants of probation in cases for which the punishment prescribed is equal to, or less than, the punishment for robbery, burglary, or arson. However, several of the crimes enumerated in ( 8 ) have lesser punishments than those three crimes. Robbery or burglary in the first degree are punishable by imprisonment for "not less than five years." CAL. PEN. CODE $\$ \S 213$, 461. Arson is punishable with imprisonment for two to twenty years. CAL. PEN. CodE $\$ 447$ a. On the other hand, rape is punishable by imprisonment for not less than three years. CAL. PEN. CODE § 264. Assault with intent to commit murder is punisbable by a one to fourteen year sentence. CAL. PEN. CODE $\S 217$. Thus the standard becomes indeterminable and the solution more apparent than real. Further, the prescribed punishment is at best a very rough ineasure of the stereotyped social wrong committed.

50 People v. Southack, 39 Cal. 2d 578, 248 P.2d 12 (1952) (manslaughter-deadly weapon); People v. Henderson, 151 Cal. App. 2d 407, 311 P.2d 594 (1957) (assault-deadly weapon); People v. Johnson, 140 Cal. App. 2d 613, 295 P.2d 493 (1956) (manslaughter-deadly weapon); People v. Pilgrim, 73 Cal. App. 2d 391, 166 P.2d 636 (1946) (manslaughter-bodily injury); People v. Harshaw, 71 Cal. App. 2d 146, 161 P.2d 978 (1945) (assault with intent to rapedeadly weapon).

61 People v. Doyle, 162 Cal. App. 2d 158, 328 P.2d 7 (1958), seems by implication to have accepted this argument. But cf. People v. Orrante, 201 A.C.A. 614, 20 Cal. Rptr. 480 (1962), where the court declined to consider the question of whether the "unusual cases" provision was applicable to all offenses. 
fourth paragraph (part (8)). Thus, it appears a compromise was reached although, from the legislative history, it is not certain how far this compromise was intended to hiberalize the statute. Nevertheless, if one assumes, instead of legislative ineptness, that the legislature intended to formulate a consistent scheme of restrictions, some logic can be found in the statute. The scheme can be illustrated by examining the restrictions on probation associated with prior felonies. No defendant can be granted probation who has been convicted of two prior felonies. ${ }^{62}$ If the defendant has been convicted of a crime enumerated in $(9 a)$, he cannot be granted probation if he has been convicted of one prior felony. The 1957 change ${ }^{63}$ made it clear that a defendant convicted of robbery, burglary, or arson, who had a prior felony conviction could be granted probation in "unusual cases." This indicates three categories of offenses which, in order of strictness of eligibility for probation, are: (1) the offenses enumerated in $(9 a) ;(2)$ robbery, burglary, and arson; and (3) all other offenses. Except for extortion and violations of Penal Code sections 286,288 , and 288a, the offenses enumerated in $(9 a)$ are the same as those in $(8)$. They can be assumed to be subject to the inost rigorous restrictions on probation. If the prior felony scheme can be followed, then all other offenses would be restricted less rigorously than the offenses enumerated in $(8)$ and to no greater extent than robbery, burglary, and arson. Therefore, it would be possible to grant probation in "unusual cases" to all offenders other than those convicted of offenses enumerated in $(8) .55$ This would be the preferable interpretation.

Eligibility for probation is determined by the court. The language of the statute makes this explicit with relation to prior felonies. No defendant can be granted probation "unless the court shall be satisfied" that he has not been convicted of a prior felony. Although this language would seen to imply that the jury can decide the question of eligibility in cases where the restriction does not relate to prior felonies, the case law indicates otherwise. ${ }^{56}$

A final question that is presented is whether or not the restrictions are apphcable to inisdemeanors. While the case law does not establisl that they are, ${ }^{67}$ there is nothing to indicate otherwise and they are probably so treated in practice.

\section{II}

\section{A CRITIQUE OF THE RESTRICTIONS OF ELIGIBILITY}

Recent literature pertaining to probation leaves the impression that specific restrictions on judicial ability to grant probation, like those contained in Penal Code section 1203, are not considered realistic and should be discarded. ${ }^{68}$ In Eng-

52 See appendix, part $(8 c)$ of statute.

53 Cal. Stat. 1957, ch. 2054, § 1, at 3648 (Senate bill 2279).

54 The language used by the legislature to designate which persons come under the restrictions, "nor to any such person," obviously refers back to "person who shall' have been convicted of robbery, burglary or arson."

55 But see note 51 supra.

56 See People v. Southack, 39 Cal. 2d 578, 248 P.2d 12 (1952); People v. Johnson, $140 \mathrm{Cal}$. App. 2d 613, 295 P.2d 493 (1956). The court is not bound by the elements of the offense to which the defendant pleads guilty. People v. Hollis, 176 Cal. App. 2d 92, 1 Cal. Rptr. 293 (1959).

57 See Comment, Sentencing in California, 13 Starr. L. REv. 340, 343 n.18 (1961).

58 See generally U.N., The Selection of OfFenders for Probation 64 (1959); U.N. Dep'T of Soctar Affatrs, Probation and Related Measures 223 (1951); Welscher, Sentencing, Correction and the Model Penal Code, 109 U. PA. L. REv. 465, 470-72 (1961). 
land, ${ }^{59}$ the United States federal courts, ${ }^{60}$ and several states, ${ }^{81}$ the restrictions are nonexistent or minimal. In California, relaxation of the restrictions was the apparent aim of Senate bill 2279 as originally introduced. ${ }^{62}$ When the criticisms, the probation laws in other jurisdictions, and the attempts to nodify California's law are viewed in relation to the intricacy of the provisions, the question arises whether the restrictions are desirable. More specifically, how rational are the restrictions? Do they produce any favorable or unfavorable side effects? What would be the practical effect if the restrictions were removed? While no precise answers to these questions will be attempted in the analysis that follows, general problem areas will be discussed and possible deficiencies in the restrictions will be indicated.

Probation as a method of deahing with convicted offenders is only a means to accomplish the desired ends of the criminal law. Since restrictions are limiting devices, one must inquire whether they serve these purposes.

Traditionally, the justification of criminal law has been considered retribution. In the past one hundred years, however, this rationale has come into disrepute; with a more humanitarian, utilitarian, and scientific view of crime, the emphasis luas been placed on reformation of the criminal and deterrence $e^{63}$ of potential crime. ${ }^{64}$ It is not the purpose of this comment to evaluate the importance which should be placed on each of these ends. It will be assumed arguendo that all three are of consequence. Thus, if the restriction tends, in a positive manner, to achieve these three ends of the criminal law, it may be considered valid. If on the other hand the restriction is negatively related to these ends, it should be considered invalid since it tends to make probation unavailable in those cases in which it sliould be granted.

Restrictions like those contained in section 1203 tend to relate to the conduct that society considers most offensive. ${ }^{65}$ In California this statement tends to hold true. A defendant who commits murder, or rape with force and violence, and is

${ }^{60}$ All offenders except those guilty of murder, high treason, piracy or arson of the Queen's ships are eligible. CaMbridge University, Dep't of Crimtral ScIEnce, The Resuits of Probatron at xii (1958) [hereinafter cited as The Results of Probatron].

6018 U.S.C. \& 3651 (1958) denies probation to those convicted of an offense "punishable by death or hife imprisonment."

61 There are no restrictions in Maryland, New Hampshire, New Jersey, Oregon, Utah, Vermont, and Wisconsin.

62 In a report primted in January 1957, the removal of restrictions in all cases, except where the death penalty or life imprisonment are the prescribed penalties, was recommended. STate of Carif., Second Intertar Report of Spectal Study Commission on Correctionar Factirtirs and Services, Probation, Jails and Parole 13, 22 (1957).

Later that year, but subsequent to the passing of the present law, the removal of the restrictions was again recommended. PROBATION IN CALIForNia 23. It also appears from the history of the 1949 amendment that the elimination of the restrictions was considered at that time. Compare A.B. 2589, Cal. Leg., Reg. (Gen.) Sess. (1949), as originally introduced, with Cal. Stat. 1949, ch. 1329, § 1, at 2324.

63 The deterrent effect that is discussed here is the effect on the potential offender population as a whole and not on the particular individual who may receive probation.

64 On the history of the social philosophy towards crime see CHute \& BerI, CrTMEs, Courts and Probation 1-9 (1956); Dressler, Practice and Theory of Probation and Parole 1-5 (1959); Watte, The Prevention of Repeated Crime (1943).

65 2 U.S. Dep'T of Justice, Attorney Generat's Survey of Release Procedures 115 (1939) [hereinafter cited as 2 AtToRNEy GeNerar's SURvey]. 
armed with a deadly weapon cannot receive probation. ${ }^{66}$ This is also true with respect to persons who use a deadly weapon, inflict great bodily injury or torture, or those with prior offenses. Nevertheless, the extreme intricacy of the restrictions cannot be justified on this basis, nor can specific restrictions such as those on trainwrecking or bribery by public officials. These can probably best be explained as legislative reactions to a particular situation. For example, the public official restriction may be a result of a fear that officials could influence the courts to grant probation to them.

Little factual information is available on the effects of probation, in general, on the deterrence of crime. ${ }^{67}$ Even if there were, deterrence should be considered in a more sophisticated manner than merely talking broadly in terms of all crimes. Is the effect of the possibility of probation the same in a case of rape with force or violence while armed with a deadly weapon, as it is in a bad check case? Is the potential inflicter of bodily injury or torture likely to consider the effects of probation? While no defimitive answers can be given to those questions it slould not be assumed that the offenses specified in section 1203 are uniformly the crimes that are likely to be deterred. Further, the deterrence argument assumes that potential criminals know of, and understand, the provisions of section 1203. This may be doubtful, especially in view of the difficulties in interpretation experienced by lawyers and judges. Thus, while it cannot definitely be said that the restrictions are negatively related to the deterrent goal of the criminal law, neither can the restrictions be said to uniformly and definitely support this goal.

The restrictions are so intricate as to assume a kind of scientific sanctity. It miglit be thought that they were designed to exclude those persons wlio possess the least possibihities for reformation. This is unlikely, for sociological prediction niethods liave not yet reached that stage of sophistication as to enable the legislature to specify, with the preciseness contained in the statute, those crimes in which recidivism is hikely to be high. ${ }^{68}$ The studies that have been made tend to confirm the fact that persons with prior convictions are generally poorer probation risks than first time offenders. ${ }^{69}$ Yet, it ean still be asked whether a person with a prior armed felony conviction is a poorer risk than a person with ten misdemeanor convictions.

While no studies have been found that consider the recidivism rate of persons committing certain crinies while armed with deadly weapons, studies made do indicate that recidivism is not signiflcantly related to the type of offense committed.70 Rates of revocation of probation in California tend to cast doubt on the validity of the proscriptions; they indicate that defenclants who are convicted of forgery or passing bad checks are more likely to be recidivists than killers, sex offenders,

${ }^{66}$ Judged by the legislatively imposed punishments, however, the offenses enumerated in $\$ 1203$ are not always the most offensive. See note 49 supra.

67 However, Timasheff, as a result of an examination of crime rates in several European countries preceding, and subsequent to, the introduction of probation, concluded that there was no adverse effect on crime rates due to probation. TMMASHEFF, Probation IN THE LioHT OF Crmitnal Statistics 5-7 (1949).

68 See Monachesi, Evaluation of Recent Major Efforts at Prediction, 6 AMrrican SocroIOGICAL Rev. 478-86 (1941); Reeves, A Fresh Look at Prediction and Supervision, 7 Crome \& Delinquency 37 n.1 (1961).

69 See The Results of Probation 5-10; 2 Attorney Generax's Survey 387-93.

70 See Probation tn Cartfornta 104; 2 Attorney General's Survey 393-400. 
and other criminals within the purview of the statute..$^{71}$ Of course, the risk to society in releasing the defendant must be measured not only with regard to the likelihood of the offense but with the gravity of the offense that might be committed. To the extent that persons will repeat the types of crimes committed, the statute does place emphasis on the potential danger to society. ${ }^{72}$

The ability of probation to serve the reformative ends of the criminal law can not be viewed in a vacuum. Rather, probation must be considered in relation to other methods available. Normally, incarceration with eventual release ${ }^{73}$ is the alternative to probation. Studies of the comparable success of probationers and those committed to mstitutions are not really possible because those granted probation will generally be better cases for reformation than those committed to prisons. There are two a priori, nonquantified arguments for probation. First, by using probation the defendant avoids the bad associations of the hardened criminal group in prison. Second, probation obviates the stigma placed on the "ex-con." This aids in the rehabilitation process for it tends to make jobs more available to the defendant. The opposing argument is that a period of incarceration will cause the defendant to have the necessary respect for the law-or at least the authority of the state. Both sides of this argument probably have some degree of validity when applied to individual situations. Relative to any particular restriction, does one argument have greater weight than the other? Considering the type of restriction which prohibits probation because of prior felony, it can be assumed that those who have been convicted of prior felonies would tend to be already hardened; still they may or may not be impressed with incarceration. ${ }^{75}$ It would seem that restric-

71 From a study of the violation status of adult defendants granted probation in California superior courts during 1955, with Los Angeles and Alameda Counties excluded, the following rates are available:

$\begin{array}{lc}\text { OFFENSE TYPE } & \begin{array}{c}\text { PERCENTAGE OF } \\ \text { vIOLATORS AS OF } \\ \text { DEC. } 31,1960\end{array} \\ \text { Manslaughter } & 20.0 \\ \text { Manslaughter, vehicle } & 13.9 \\ \text { Robbery } & 30.3 \\ \text { Assault } & 17.7 \\ \text { Burglary } & 35.9 \\ \text { Theft, except auto } & 29.6 \\ \text { Auto theft } & 46.1 \\ \text { Forgery and checks } & 54.9 \\ \text { Narcotics } & 38.7 \\ \text { Lewd and lascivious conduct } & 14.1 \\ \text { Deadly weapons } & 7.2 \\ \quad \text { ovERALL AVERAGE } & 34.0\end{array}$

Source: State of Calif., Dep't of Justice, Bureat of Crimitat Statistics, Delinquency and Probation in California 1960, at 176, table V-23.

72 See 2 Atrorney General's Survey 400, where it is concluded: "When violation does occur, probationers seem inclined to return to a crime similar $\mathrm{m}$ nature to the original offense."

73 Over $98 \%$ of those incarcerated are eventually released. STATE of CAIIF., DEP'T OF CORrections, Catifornda Prisoners 1960, at 48. In 1960, $85.3 \%$ of the men and $96.1 \%$ of the women released were placed on parole. $I d$. at 49.

74 See note 13 supra.

75 An early study by the Gluecks indicated that a relationship did exist between the prior record of the defendant and the success after release from incarceration. Glueck \& Glueck, Predictability in the Administration of Criminal Justice, 42 HARv. L. REv. 300, 310-11 (1928). However, the follow up on this study, Glueck \& Glokck, CrIMtnal Careers in Retrospect 284 (1943), tends to shed some doubt on the importance of this factor. 
tions that tend to prohibit probation according to the crime committed or conduct of the defendant are even less correlated with the reformative effect of incarceration. ${ }^{76}$ Thus, vis-á-vis reformation, these restrictions tend to be negatively related to the ends of criminal law.

The above analysis assumes that restrictions on probation are theoretically desirable. It posits some decisional error on the part of the judge and assumes that by specifically limiting the area in which the judge can grant probation, the error that will be committed is minimized. It does not assume that the restrictions produce no error at all. Thus, the argument that restrictions per se are bad, because of error caused by the inability of the court to consider the particular circumstances of the case, has not been considered. This error is accepted in the broad legislative assumptions of section 1203. It is the relative quantum of error, not its existence, that is important. The criticism presented, however, indicates that the present restrictions do not limit probation as wisely ${ }^{77}$ as might be assumed by their intricacy and may not be the most desirable restrictions. It may be that it is not possible to articulate restrictions which are precise enough to accomplish the "ends of justice" in a more acceptable manner than would be the result if the judge made his decision unhampered by legislative restrictions.

Three possible side effects, while not capable of quantitative analysis, are of interest. The first is that probation makes available a method of dealing with persons who have committed a crime and who might not otherwise be dealt with at all. When the legislatively imposed punishment for a crime is too rigorous, complaints may not be filed and convictions may not be forthcoming. To the extent that this generalization has validity, it would appear that a potential danger area lies not so much with Penal Code section $1203^{78}$ but in another statute restricting probation-Health and Safetv Code section 11715.6. which limits probation in narcotics cases. The second side effect is that even if the case does get prosecuted, and guilt is established, the decision as to who is eligible for probation may rest with the prosecuting attorney rather than the trial iudge. This is accomplished bv methods such as disregarding the fact that the defendant was armed with a deadlv weapon - "swallowing the gun" -or that he has had prior felony convictions. ${ }^{70}$ This situation is unsuitable in that it tends to disregard the legislative intent. Nevertheless, these practices may be a closer approach to the realities of the particular situation and therefore cast doubt on the validity of the restrictions.

A favorable side effect of the restrictions is that they tend to produce a more uniform manner of dealing with convicted defendants. ${ }^{80}$ It is open to question if

${ }^{76}$ See Glueck \& Glueck, supra note 75, at 305, where the rejationship between the type of offense and the post-parole success was described as "negligible." See also Grueck \& GLUECK, Crominal Careers in Retrospect 291 (1943).

77 For a clear case of the restrictions at their worst see People v. Walters, $190 \mathrm{Cal}$. App. 2d 98, 11 Cal. Rptr. 597 (1961). There the defendant, convicted of a violation of CaL. PEN. CODE $\$ 288$ in 1959, had a prior felony conviction in 1937. He was inehigible for probation under the law.

78 Under $\$ 1203$ the offense for which this effect is likely to be important is intrafamily assaults with a deadly weapon.

70 See People v. Gottlieb, 25 Cal. App. 2d 411, 414, 77 P.2d 489, 491 (1938), for the manner in which the practice works.

80 In 1961, the proportion of probation grants to convictions ranged from $61.5 \%$ in Lake County to $23.5 \%$ in Del Norte County. Seven counties which had over 500 convictions each accounted for over three quarters of the felony convictions. In those counties, the range was from $31.9 \%$ in Kern County ( 505 convictions) to $53.5 \%$ for Alameda County (1,299 convictions). Los Angeles, with over one half of the state's felony convictions, had a rate of $48.1 \%$. Crmare tn CatIfornta 1961, at 122-23. 
this is the best way of obtaining the desired uniformity. Further, the conduct for which, and persons to whom, the statute denies probation are probably those in which the judges would agree most often about in making their probation decisions.

What would be the actual effect if the restrictions were lifted? The information available indicates that there would be no really significant change. At the start it should be stressed that the alternative to the restrictions is not letting all the defendants convicted of crimes loose in society. This is borne out by the impressions of judges who indicated that in their opinion a very small percentage of those now ineligible under the statute would be potential probationers. ${ }^{81} \mathrm{~A}$ somewhat larger percentage was indicated by probation officers. ${ }^{82} \mathrm{~A}$ further indication is the response to the 1957 amendment. ${ }^{83}$ As might be expected, total probation grants remained relatively constant during the years of 1955 to $1961 .{ }^{84}$ This indicates a relatively uniform attitude of the judges to probation in general. The 1957 amendment relaxed the restrictions on probation grants to armed robbers, burglars, and arsonists. If the loosening of legislative restrictions was a signal for judicial recklessness, one would expect to see a rise in the rate of probation granted to persons convicted of these crimes. This apparently has not been the case according to the data available for burglary and robbery. Over the past seven years the percentage of probation granted for burglary remained relatively constant. ${ }^{85}$ More interesting are the figures for robbery. While the proportion of armed robberies remained relatively constant, ${ }^{86}$ the percentage of probation granted in cases of

81 Of forty-two superior court judges who were asked what per cent of those ineligible for probation were good prohation risks, fifteen indicated 1 or $2 \%$; eight, $5 \%$ or less; five, 5 to $10 \%$; one, perhaps $1 / 3$; and ten judges made no estimate. Probation IN CaIIFORNIA 37.

82 Ibid.

83 Cal. Stat. 1957, ch. 2054, $\$ 1$, at 3648 (Senate bill 2279).

84 See note 2 supra.

85

$\begin{array}{lc}\text { PERCENTAGE OF } \\ \text { PEAR } & \begin{array}{c}\text { PROBATION GRANTS TO } \\ \text { BURGLARY CONVICTIONS }\end{array} \\ 1955 & 38.5 \\ 1956 & 39.7 \\ 1957 & 40.7 \\ 1958 & 44.6 \\ 1959 & 36.3 \\ 1960 & 39.7 \\ 1961 & 40.9\end{array}$

Source: Crman In CarIFornia 1955, at 61, table 30; 1956 at 72, table 27; 1957 at 82, table 33 ; 1958 at 73 , table $30 ; 1959$ at 85 , table $33 ; 1960$ at 115 , table VI-19; 1961 at 124 , table VI-18.

The rapid increase in the rate of probation grants in 1958 might be explained as due to the easier restrictions on prohation. Indeed, it appears that the general increase in prohation during that year was due to the increase in grants of probation in burglary cases. However, it is not known what percentage of the increases was to armed burglars.

88 Figures available for 1955 to 1958 , and 1960 , indicate the per cent of armed rohberies reported was about two-thirds of the total robberies reported.

$\begin{array}{lc} & \text { PERCENTAGE OF ARMED } \\ \text { ROBBERIES REPORTED TO TOTAL } \\ \text { ROBBERES REPORTED } \\ 1955 & 59.5 \text { (second half of year only) } \\ 1956 & 61.6 \\ 1957 & 62.1 \\ 1958 & 65.5 \\ 1960 & 63.0\end{array}$

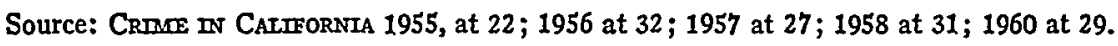


robbery actually fell after the 1957 amendment..$^{87}$ Further, if the restrictions were removed, a great percentage of those persons granted probation who are now ineligible would probably be given terms in jail as a condition to probation. ${ }^{88}$

Thus, it would appear that no large scale release of dangerous felons would be effectuated if the restrictions were removed. Of course, there are bound to be some mistakes and some revocations will be necessary but this is true of the system of probation as a whole. ${ }^{89}$ There is nothing to indicate that, with careful and intelligent selection of offenders for probation by the judiciary, the system would fail to work satisfactorily without any restrictions.

\section{III}

\section{LEGISLATIVE PROPOSATS}

The following is intended to contain, with minor exceptions, the substance of the present Penal Code sections 1203 and 1204 while eliminating the constructional problems that have been considered in part I of this comment:

Presentence Report. After conviction ${ }^{90}$ by plea or verdict or finding ${ }^{91}$ of guilty and before judgment is pronounced, whether or not an application lias been made, ${ }^{92}$ the court in every felony case must, ${ }^{93}$ and in any misdemeanor case may, ${ }^{94}$ refer the matter to the probation officer to investigate and report, at a time specified, upon the circumstances surrounding the crime and concerning the defendant and his prior record and history.

Upon referral the probation officer must make the ordered investigation ${ }^{95}$

87

$\begin{array}{lc} & \begin{array}{c}\text { PERCENTAGE OF } \\ \text { PROBATION GRANTS TO }\end{array} \\ \text { YEAR } & \text { ROBBERY CONVICTIONS } \\ 1955 & 22.6 \\ 1956 & 23.2 \\ 1957 & 27.5 \\ 1958 & 27.7 \\ 1959 & 21.1 \\ 1960 & 20.8 \\ 1961 & 23.3\end{array}$

Source: Crmme In CaImornia 1955, at 61, table 30; 1956 at 72, table 27; 1957 at 82, table 33 ; 1958 at 73 , table $30 ; 1959$ at 85 , table $33 ; 1960$ at 115 , table VI-19; 1961 at 124 , table VI-18.

The 1957 amendment became law in September and so it cannot be assumed that the increase in 1957 was due to the amendment. While the 1958 rate remained relatively constant, the rate in 1959 and 1960 fell below the previous rate.

88 See note 12 supra.

89 It is estimated that probation is effective in about $70 \%$ of the cases in California. See Probation IN Calmornia 90. This figure roughly approximates figures arrived at in other studies. See Chfford, Why Does Probation Work, 123 Justice of THE PEACE 123 (1959); THE Results of Probation 34 ; Probation in Calmornia 92. On these studies generally, see Tappan, Crmare, Justice and Correction 576-81 (1960).

90 See note 36 supra and accompanying text.

91 See note 37 supra and accompanying text. The word "finding" is included in order to cover the cases heard by a court.

92 See notes 39, 40 supra and accompanying text. Since in misdemeanor cases the presentence report is discretionary with the court, it can, but need not, require a report without application by the defense or prosecution.

93 See text accompanying notes 17-19 supra. The requirement of a presentence report in every felony case, whether the defendant is eligible for probation or not, is a change from the present statute.

94 See note 21 supra and accompanying text.

95 The repetition of what inust be reported is eliminated. See note 23 supra. 
and must make a written report to the court of the facts found upon such investigation, and must accompany said report with his written recommendations, including his recommendations as to the granting or withholding of probation to the defendant and as to the conditions of probation if it shall be granted.

The report and recommendations must be made available to the court and the prosecuting and defense attorneys at least two days prior to the time fixed by the court for hearing and determination of such report and must be filed with the clerk of the court as a record in the case at the time of said hearing. By written stipulation of the prosecuting and defense attorneys, filed with the court, or by oral stipulation in open court made and entered on the minutes of the court, the time within which the report and recommendations must be made available and filed, under the preceding provisions of this section, may be waived.

In cases where probation is not granted, the report and recommendations made by the probation officer shall forthwith be sent, by the clerk of the court, to the Department of Corrections at the prison or other institution to which the defendant is dehivered.

Hearing. The court shall, in the presence of the defendant, ${ }^{96}$ hear and determine the matter of probation in cases in which the defendant is eligible for probation, ${ }^{97}$ and shall hear and determine the matter of the extent of punishment in cases in which it has discretion to do so. ${ }^{88}$ The court must consider any report made by the probation officer and must make a statement that it has considered such report which must be filed with the clerk of the court as a record in the case. The court may consider any circumstances in mitigation or aggravation of punisliment if they are contained in such report or are presented by the testimony of witnesses examined in open court. ${ }^{99}$ However, when a witness is so sick or infirm as to be unable to attend, his deposition may be taken upon such notice as the court may direct.

In misdemeanor cases where no presentence report has been required by the court, the court may summarily deny or summarily grant probation. ${ }^{100}$

Probation Authorized. If the court shall determine that the ends of justice ${ }^{101}$ would be subserved by granting probation it shall have the power to place any eligible defendant on probation as provided for in this chapter. ${ }^{102}$

No defendant shall be eligible for probation who:

(1) Shall have been convicted of a crime for which the death penalty or hife imprisonment without possibility of parole is the mandatory punishment. ${ }^{103}$

(2) Shall have been convicted of burglary with explosives, rape with force or violence, murder, assault with intent to commit murder, attempt to commit murder, trainwrecking, kidnapping, escape from a state prison, conspiracy to commit any one or more of the aforementioned felonies, and who at the tine

96 See note 30 supra and accompanying text.

87 See note 18 supra.

98 See note 29 supra and accompanying text.

99 See note 31 supra; CAL. Pen. Code § 1204.

100 This sentence is imcluded to make it clear that the court may, in misdemeanor cases, grant or deny probation without a presentence report. See appendix, part ( $\sigma)$ of statute.

101 See text accompanying note 43 supra.

102 See notes 32-34 supra and accompanying text. CAL. PEN. CODE $\$ \$ 1203,1203.02,1203.1$, and 1203a are all in the same chapter of title VIII of the Penal Code. As to CAL. PEN. CODE $\$ 1215$, see recommendation in text accompanying note 110 infra.

${ }^{103}$ See note 42 supra and accompanying text. 
of the perpetration of said crime or at the time of his arrest was himself armed with a deadly weapon (unless at the time he had a lawful right to carry the same), nor to such a defendant ${ }^{104}$ who used or attempted to use a deadly weapon upon a human being in connection with the perpetration of said crime, nor to such a defendant who im the perpetration of said crime wilfully inflicted great bodily injury or torture.

(3) Shall have been ${ }^{105}$ twice previously convicted of a felony in this state or twice previously convicted in any other place or places of public offenses which would have been felonies if committed in this state.

(4) Shall have been convicted of any offense enumerated in restriction (2) above or extortion or violation of sections 286,288 , or 288a of this Code or conspiracy to commit any one or more of the aforesaid felonies and who shall lave previously been convicted of a felony in this State or previously convicted in any other place of a public offense which would have been a felony if committed in this State.

(5) Shall have been previously convicted of a felony in this State or convicted in any other place of a public offense which would have been a felony if committed in this State and at the time of the perpetration of said previous offense, or at the time of arrest for said previous offense was himself armed with a deadly weapon (unless at the time he had a lawful right to carry the same), or personally used or attempted to use a deadly weapon upon a liuman being in connection with the perpetration of said previous offense, or in the perpetration of said previous offense wilfully inflicted great bodily injury or torture.

(6) Is a public official or peace officer of the state, county, city, city and county, or other political subdivision who, in the discharge of the duties of his public office or employment, accepted or gave or offered to accept or give any bribe or embezzled public money or was guilty of extortion.

The Legislature hereby expresses the policy of the people of the State of California to be that, except in unusual cases where the interest of justice demands a departure from the declared policy, no judge shall grant probation to any person who:

(A) Shall have been convicted of robbery, burglary or arson and who at the time of the perpetration of said crime or at the time of his arrest was himself arnied with a deadly weapon, or to any such person who has previously been convicted of a felony in this State or previously convicted in any other place of a public offense which would have been a felony if committed in this State. ${ }^{108}$

(B) Used or attempted to use a deadly weapon upon á human being in connection with the perpetration of any crime not enumerated in (2) of which lie was convicted, nor to one who in the perpetration of any crime not enumerated in (2) of which he was convicted inflicted great bodily injury or torture. ${ }^{107}$

104 This would make the bodily injury and use of deadly weapon restrictions applicable only to those crimes enumerated in (2). See discussion of specific limitations in text accom. panying notes 44-55 supra.

105 The provision which reads "unless the court shall be satisfied" has been deleted throughout the proposed statute. See note 56 supra and accompanying text.

${ }^{106}$ See note 54 supra and accompanying text.

107 See note 104 supra. 
Persons included in (A) and (B) are eligible for probation within the meaning of this section. ${ }^{108}$

If the legislature should decide to abolisl the restrictions on judicial ability to grant probation, the portion of the proposed statute from "No defendant shall be eligible ..." to the end of the statute could be eliminated. Assuming that the legislature would still want to keep restriction (1), this could be accomplished by changing the paragraph of the proposed statute, which authorizes probation, to read:

Probation Authorized. If the court shall determine that the ends of justice would be subserved by granting probation it shall have the power to place any defendant, who has not been convicted of a public offense for which the mandatory punisliment is death or life imprisonment without possibility of parole, on probation as provided in this chapter.

The legislature might wisl to remove the restrictions but at the same time express their intent to restrict tle use of probation in certain situations to "unusual" cases. This could be accomplished by substituting the phrase "the Legislature hereby expresses the policy ... that, except in unusual cases . . . no judge shall grant probation . . . who," for "no defendant is eligible for probation who," and by deleting part (1) which would have its contents expressed in the first paragraph of the statute; deleting (A) and including robbery, burglary, and arson in (2); deleting that part of (2) reading "nor to such a defendant who used . . . great bodily injury or torture"; and by renumbering (B) as (1), and deleting the language reading "not enumerated in (2)."

Other necesary or desirable action by the legislature includes transfering the provision dealing with out-of-state probationer supervision from section 1203 to section $1203.1 ;^{109}$ deleting the surplusage in Penal Code section $1215 ;^{110}$ resolving the apparent conflict between Penal Code sections 1203.1 and $1203 \mathrm{a} ;{ }^{111}$ removing the report requirement of Penal Code section $1203 c{ }^{112}$ and generally overhauling the other statutes dealing with probation and renumbering them.

\section{CONCLUSION}

Penal Code section 1203, with its long history of amendments, has come down to us as a complicated, ambiguous, and lengthy statute. While the statute proposed by this comment may leave questions unanswered, it is believed that it does clarify the existing situation. The analysis of the restrictions on the full use of probation indicates that they are not the result of an informed inquiry into the best use to be made of probation but rather seem to be reactions to the immediate situation. While they are not completely without validity, they could probably be eliminated with little or no loss to society. The philosophy of the restrictions seems to assume an incompetent judiciary. If, and to the extent that, this is true, the legislature should educate the judiciary as to the purposes and natural limitations of probation rather than setting up artificial restrictions which, in individual cases, do not reflect the realities of the situation.

David H. Melnick

108 See note 18 supra.

109 See discussion in text following note 40.

110 See note 35 supra.

111 See note 34 supra.

112 See discussion in paragraph of text following note 25 . 


\title{
APPENDIX
}

\author{
California Penal Code section 1203, with parenthetic numerals and footnotes added, pro- \\ vides as follows:
}

(1) After the conviction by plea or verdict of guilty of a public offense not amounting to a felony, in cases where discretion is conferred on the court or any board or commission or other authority as to the extent of the punishment, the court, upon application of the defendant or of the people or upon its own motion, may summarily deny probation, or at a time fixed may hear and determine in the presence of the defendant the matter of probation of the defendant and the conditions of such probation, if granted. (2) If probation is not denied, and in every felony case in which the defendant is elgible for probation, before any judgment is pronounced, and whether or not an application for probation has been made, the court must immediately refer the matter to the probation officer to investigate and to report to the court, at a specified time, upon the circumstances surrounding the crime and concerning the defendant and his prior record, which may be taken into consideration either in aggravation or mitigation of punishment. (3) The probation officer must thereupon make an investigation of the circumstances surrounding the crime and of the prior record and history of the defendant, must make a written report to the court of the facts found upon such investigation, and must accompany said report with his written recommendations, including his recommendations as to the granting or withholding of probation to the defendant and as to conditions of probation if it shall be granted. (4) The report and recommendations must be made available to the court and the prosecuting and defense attorneys at least two days prior to the time fixed by the court for the hearing and determination of such report and must be filed with the clerk of the court as a record in the case at the time of said hearing. By written stipulation of the prosecuting attorney and the defense attorney, filed with the court, or by oral stipulation in open court made and entered on the minutes of the court, the time within which the report and recommendations must be made available and filed, under the preceding provisions of this section, may be waived. (5) At the time or times fixed by the court, tlie court must hear and determine such application, if one has been made, or in any case the suitability of probation in the particular case, and in connection therewith must consider any report of the probation officer, and must make a statement that it has considered such report which must be filed with the clerk of the court as a record in the case. If the court shall determine that there are circumstances in mitigation of punishment prescribed by law, or that the ends of justice would be subserved by granting probation to the defendant, the court shall have power in its discretion to place the defendant on probation as hereinafter provided; if probation is denied, the clerk of the court must forthwith send a copy of the report and recommendations to the Department of Corrections at the prison or other institution to which the defendant is debivered.

(6) In every misdemeanor case, the court may, at its option refer the matter to the probation officer for investigation and report or summarily deny probation or summarily grant probation.

(7) The legislature hereby expresses the policy of the people of the State of Californin to be that, except in unusual cases where the interest of justice demands a departure from the declared policy, no judge shall grant probation to any person who shall have been convicted of robbery, burglary or arson, and who at the time of the perpetration of said crime or any of them or at the time of his arrest was himself armed with a deadly weapon (unless at the time he had a lawful right to carry the same), (7a) nor to a defendant who used or attempted to use a deadly weapon upon a human being in connection with the perpetration of the crime of which he was convicted, $(7 b)$ nor to one who in the perpetration of the crime of which he was con. victed wilfully inflicted great bodily imjury or torture, $(7 c)$ nor to any such person unless the court shall be satisfied that he has never been previously convicted of a felony in this State nor previously convicted in any other place of a public offense which would have been a felony if committed in this State.

(8) Probation shall not be granted to any person who slall have been convieted of burglary with explosives, rape with force or violence, murder, assault with intent to commit murder, attempt to commit murder, train wrecking, kidnaping, escape from a state prison, conspiracy to commit any one or more of the aforementioned felonies, and who at the time of the perpetration 
of said crime or any of them or at the time of his arrest was himself 1 armed with a deadly weapon (unless at the time he had a lawful right to carry the same), $(8 a)$ nor to a defendant who used ${ }^{2}$ or attempted to use a deadly ${ }^{3}$ weapon upon a human being in connection with the perpetration of the crime of which he was convicted, $(8 b)$ nor to one who in the perpetration of the crime of which he was convicted wilfully inflicted great bodily injury or torture, $(8 c)$ nor to any defendant unless the court shall be satisfied that he has not been twice previously convicted of felony in this State nor twice previously convicted in any other place or places of public offenses which would have been felomes if counmitted in this State $;^{4}(9 a)$ nor to any defendant convicted of the crime of burglary with explosives, rape with force or violence, murder, attempt to commit nurder, assault with intent to commit murder, train wrecking, extortion, kidnapping, escape from a state prison, violation of Sections 286,288 or 288 a of this code or conspiracy to commit any one or more of the aforesaid felonies, unless the court shall be satisfied that he has never been previously convicted of a felony in this State nor previously convicted in any other place of a public offense which would have been a felony if committed in this State; $(9 b)$ nor to any defendant unless the court shall be satisfied that he has never been previously convicted of any felony in this State nor convicted in any other place of a public offense which would have been a felony if committed in this State and at the time of the perpetration of said previous offense or at the time of his arrest for said previous offense he was himself armed with a deadly weapon (unless at the time he had a lawful right to carry the same) or he personally used or attempted to use a deadly weapon upon a human being in connection with the perpetration of said previous offense or in the perpetration of said previous offense lie wilfully inflicted great bodily injury or torture; $(10)$ nor to any public official 5 or peace officer of the State, county, city, city and county, or other political subdivision who, in the discharge of the duties of his public office or employment, accepted or gave or offered to accept or give any bribe or embezzled public money or was guilty of extortion.

(11) No probationer shall be released to enter another state of the United States, unless and until his case has been referred to the Califorma Administrator, Interstate Probation and Parole Compacts, pursuant to the Uniform Act for Out-of-State Probationer and Parolee Supervision.

(12) In those cases in which the defendant is not eligible for probation, the judge may in his discretion refer the matter to the probation officer for an investigation of the facts relevant to sentence. The probation officer must thereupon make an investigation of circumstances surrounding the crime and the prior record and history of the defendant and make a written reportto the court of the facts found upon such investigation.

1 The word "himself," added in 1949, overruled People v. Stevens, 32 Cal. App. 2d 666, 90 P.2d 595 (1939); People v. Lewis, 140 Cal. App. 475, 35 P.2d 561 (1934); and People v. Gillstarr, 132 Cal. App. 267, 22 P.2d 549 (1933). These cases held that an accomplice to an armed offense was inehgible for probation. See People v. Perkins, 37 Cal. 2d 62, 230 P.2d 353 (1951).

2 The "use" of a weapon must be deliberate. People v. Southack, 39 Cal. 2d 578, 248 P.2d 12 (1952) (hair-trigger gun); People v. Doyle, 162 Cal. App. 2d 158, 328 P.2d 7 (1958) (knife, during affray); People v. Johnson, 140 Cal. App. 2d 613, 295 P.2d 493 (1956) (knife).

3 Whether the weapon is deadly depends on the actual circumstances of the case. People v. Raner, 86 Cal. App. 2d 107, 194 P.2d 37 (1948). As to knives, compare People v. Henderson, 151 Cal. App.2d 407, 311 P.2d 594 (1957), with People v. Johnson, 140 Cal. App. 2d 613, 295 P.2d 493 (1956).

4 The offense must include all the elements of a felony in California, People v. Christenbery, 167 Cal. App. 2d 751, 334 P.2d 978 (1959), and a mere showing that the defendant had been sentenced to an out-of-state prison is not sufficient, People v. Brown, 172 Cal. App. 2d 30, 342 P.2d 410 (1959).

"A clerk of the Roseville Judicial District court was a "public official" within the meaning of the statute. Bennett v. Superior Court, 131 Cal. App. 2d 841, 281 P.2d 285 (1955). An auditor in charge of an audit district office was a mere employee and thus eligible for probation. Schaefer v. Superior Court, 113 Cal. App. 2d 428, 248 P.2d 450 (1952). 